\title{
32. OXYGEN ISOTOPIC COMPOSITION OF BASALTS FROM LEG 65, DEEP SEA DRILLING PROJECT ${ }^{1}$
}

\author{
S. Hoernes ${ }^{2}$ and H. Friedrichsen, Mineralogisches Institut, Abteilung Geochemie, Universität Tübingen, \\ 7400 Tübingen, Federal Republic of Germany
}

\section{INTRODUCTION}

In order to provide information on the degree of alteration of the very young basaltic basement drilled on Leg 65 in the mouth of the Gulf of California, we have measured the oxygen isotopic composition of whole rocks and mineral separates. Considerable data already exist for older ocean crust, in particular for the deep holes drilled in the Atlantic Ocean on Deep Sea Drilling Project (DSDP) Legs 37, 45, 46, and 51-53. These data indicate that in all of these holes, which include crust as young as $3.5 \mathrm{~m} . \mathrm{y}$. old, a significant amount of alteration has taken place as the result of low-temperature interaction between basalt and seawater (cf. Muehlenbachs, 1977, 1980; Hoernes et al., 1978; Friedrichsen and Hoernes, 1980). It is therefore of interest to determine whether Leg 65 crust, which is only 0.5 to 1.5 m.y. old, has experienced a similar degree of alteration.

\section{EXPERIMENTAL TECHNIQUES}

Minerals were separated from 14 rock samples using standard techniques. Oxygen was extracted from mineral and whole rock samples using the bromine pentafluoride procedure (Clayton and Mayeda, 1963). Details of sample preparation are given elsewhere (Hoernes and Friedrichsen, 1978). Selected whole rock samples were also analyzed for hydrogen isotope composition, following preparation using the method described by Godfrey (1962). Oxygen and hydrogen isotope compositions are reported in the usual $\delta$-notation relative to SMOW (Standard Mean Ocean Water). Carbonate data are reported relative to the PDB standard. Routine reproducibility of $\delta^{18} \mathrm{O}, \delta \mathrm{D}$, and $\delta^{13} \mathrm{C}$ values is typically $0.15 \%, 2 \%$, and $0.05 \%$, respectively.

\section{RESULTS AND DISCUSSION}

\section{Whole Rocks}

The stratigraphic locations of the basalt samples, which are from five separate holes, are shown in Figure 1 . The oxygen isotope composition of whole rock samples and mineral separates is given in Table 1. Whole rock hydrogen isotope data for selected samples are presented in Table 2. The $\delta^{18} \mathrm{O}$ values of the whole rocks range from 5.3 to 6.8 , with an average of 6.0 . Six of the fourteen samples have $\delta^{18} \mathrm{O}$ values within the range of essentially unaltered midocean ridge basalts, which typically have values of $5.8 \pm 0.3 \%$ (Taylor, 1968; Muehlenbachs and Clayton, 1972).

\footnotetext{
${ }^{1}$ Lewis, B. T. R., Robinson, P., et al., Init. Repts. DSDP, 65: Washington (U.S. Govt. Printing Office)

2 Present address: Mineralogisches-Petrographisches Institut, Universität Bonn, 5300 Bonn, Federal Republic of Germany.
}

By comparison, Atlantic crust ranging in age from 3.5 to about $13 \mathrm{~m} . \mathrm{y}$. is characterized by $\delta^{18} \mathrm{O}$ values of about 6 to 9, with an average of 7.5 (69 analyses; data from Muehlenbachs, 1977; Gray et al., 1977; Hoernes et al., 1978; Hoernes and Friedrichsen, 1978; Muehlenbachs and Hodges, 1978). The 110 m.y. old Atlantic crust drilled in Holes 417D and 418A shows a clustering of $\delta^{18} \mathrm{O}$ values over the range of 6 to 9.5 , but higher values are also common; the average for these two holes is 9.2 (131 analyses; data from Muehlenbachs, 1980; Friedrichsen and Hoernes, 1980). On the average, 10 to $15 \%$ of the upper 600 meters of the crust in the Atlantic has experienced low-temperature reaction with seawater (Muehlenbachs, 1980; Friedrichsen and Hoernes, 1980).

A possible explanation for the relatively low $\delta^{18} \mathrm{O}$ whole rock values from Leg 65 may be related to the large proportion of massive lavas encountered at the drilled sites. As can be seen in Figure 1, a series of massive lava units, intercalated in sediments, constitutes the upper 50 meters of basement in Holes 483 and 483B, and the upper 180 meters of basement intersected by Hole 485A. In Hole 482B, the basement section drilled appears to consist almost exclusively of massive basalts. Unlike pillow lavas and lava breccias, massive basalts form laterally continuous units which are relatively unfractured internally. They can therefore decrease the overall permeability of the basement and, hence, the degree of seawater circulation.

The main alteration mineral present in Leg 65 basalts is smectite. This mineral, which replaces groundmass olivine and interstitial glass and fills sparse vesicles, constitutes up to several percent of the samples. Basalts which have reacted with seawater at low temperatures have increased $\delta^{18} \mathrm{O}$ values because hydrated secondary minerals, such as smectites, have high $\delta^{18} \mathrm{O}$ values (cf. Javoy and Fouillac, 1979). The fact that all but one of the Leg 65 basalts have $\delta^{18} \mathrm{O}$ values of $5.8 \pm 0.5 \%$ is consistent with a low degree of seawater-basalt interaction. However, temperature could also have played some role in determining the $\delta^{18} \mathrm{O}$ values. With increasing temperature, silicate-water fractionation decreases, and whole rock $\delta^{18} \mathrm{O}$ enrichment is consequently lessened. The temperature of the Leg 65 basement is relatively high, with a value of $150^{\circ} \mathrm{C}$ being recorded at a depth of only 180 meters ( $75 \mathrm{~m}$ sub-basement) in Hole $482 \mathrm{C}$ (Duennebier et al., this volume). Thus, a temperature effect on smectite $\delta^{18} \mathrm{O}$ values seems plausible. Unfortunately, the extent of such an effect cannot be assessed because of the lack of experimental data for smectites over the temperature range of interest. 


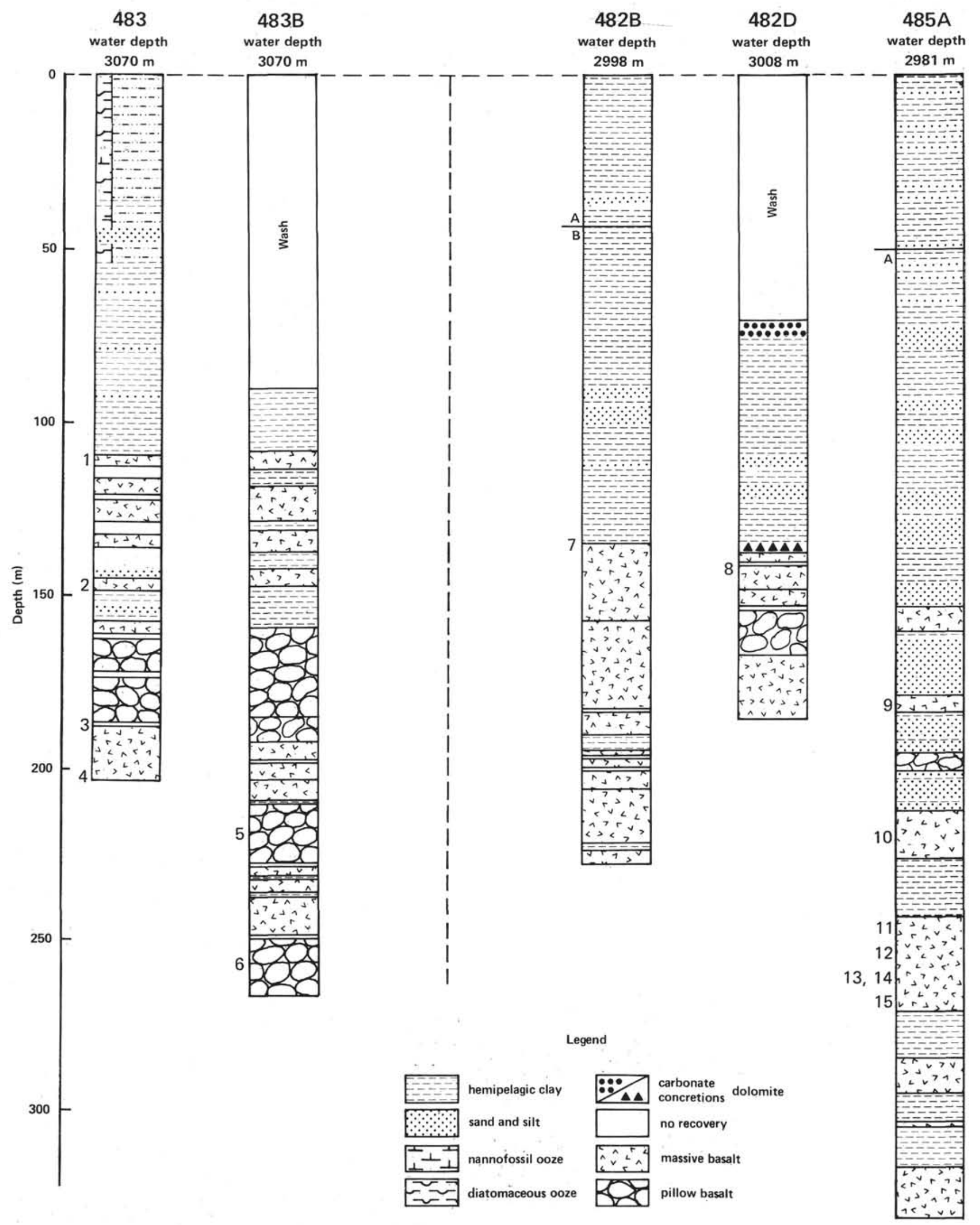

Figure 1. Stratigraphic location of analyzed basalts from Leg 65. 
Table 1. Oxygen isotope data for whole rock samples and mineral separates, Leg 65 .

\begin{tabular}{|c|c|c|c|c|c|c|c|}
\hline \multirow[b]{2}{*}{$\begin{array}{l}\text { Sample } \\
\text { No. }\end{array}$} & \multirow[b]{2}{*}{$\begin{array}{c}\text { Sample } \\
\text { (interval in } \mathrm{cm} \text { ) }\end{array}$} & \multicolumn{6}{|c|}{$\delta^{18} \mathrm{O}\left(\%_{e}\right)$} \\
\hline & & $\begin{array}{l}\text { Whole } \\
\text { Rock }\end{array}$ & Plagioclase & Pyroxene & Magnetite & IImenite & $\triangle \mathrm{Pl}-\mathrm{Mag}$ \\
\hline $1^{a}$ & $483-14-1,61-65$ & - & - & 5.0 & - & - & - \\
\hline 2 & $483-17-2,21-24$ & 6.8 & 5.6 & 4.8 & 3.6 & - & 2.0 \\
\hline 3 & $483-23-1,21-25$ & 5.9 & 5.6 & - & 3.9 & - & 1.7 \\
\hline 4 & $483-26-2,44-49$ & - & 5.6 & - & 4.0 & - & 1.6 \\
\hline 5 & $483 \mathrm{~B}-22-2,100-107$ & 6.5 & 5.7 & 5.2 & - & - & - \\
\hline 6 & $483-31-2,58-63$ & - & 5.7 & - & 3.8 & - & 1.9 \\
\hline 7 & $482 \mathrm{~B}-10-7,49-54$ & 6.0 & - & 5.3 & 3.6 & - & - \\
\hline 8 & $482 \mathrm{D}-9-1,29-35$ & 6.1 & - & - & - & - & - \\
\hline $9 \mathrm{~b}$ & $485 \mathrm{~A}-17-1,71-74$ & 0.1 & 5.5 & 4.7 & 3.3 & - & 2.2 \\
\hline 10 & $485 \mathrm{~A}-24-1,77-82$ & 5.5 & 5.5 & 5.4 & - & 3.8 & - \\
\hline 11 & $485 \mathrm{~A}-29-2,49-53$ & - & - & 5.3 & 2.3 & 3.2 & - \\
\hline 12 & $485 \mathrm{~A}-30-1,59-65$ & 6.3 & 5.9 & 5.2 & 2.8 & 3.3 & 3.1 \\
\hline $13 \mathrm{c}$ & $485 \mathrm{~A}-30-3,10-16$ & 6.0 & 5.8 & 5.1 & 3.0 & 3.6 & 2.8 \\
\hline 14 & $485 \mathrm{~A}-31-1,41-46$ & 5.3 & 5.7 & 5.5 & 3.1 & 3.3 & 2.6 \\
\hline 15 & $485 \mathrm{~A}-32-1,40-45$ & 5.8 & 5.8 & 5.2 & 2.9 & 3.4 & 2.9 \\
\hline
\end{tabular}

Another factor that could have some effect on basalt $\delta^{18} \mathrm{O}$ values is the $\delta^{18} \mathrm{O}$ composition of the seawater with which the basalts react. If the seawater has previously reacted with basalts to form smectites, it will be depleted in $\delta^{18} \mathrm{O}$ relative to its normal value. Later smectites would consequently have lower $\delta^{18} \mathrm{O}$ values, leading to somewhat lower whole rock values. For example, assuming that $10 \%$ of a basalt consists of smectite formed from normal seawater at, say, $25^{\circ} \mathrm{C}$, and that the $\delta^{18} \mathrm{O}$ value of the smectite at this temperature is about 25 (Yeh and Savin, 1977), then the initial whole rock $\delta^{18} \mathrm{O}$ value would be increased by 2.5 . If, however, the smectite formed from depleted seawater, with a plausible $\delta^{18} \mathrm{O}$ value of $-3 \%$ (Lawrence et al., 1975), then the initial whole rock value would only increase by 2.2 .

The hydrogen isotope composition of whole rock samples (Table 2) is relatively uniform: values range from -94 to $-107 \%$, with an average of $-97 \%$. These values reflect the isotope composition of smectite, which is the dominant source of hydrogen in the basalts. The limited range in $\delta \mathrm{D}$ composition is consistent with rather uniform conditions (in terms of temperature, and the $\delta \mathrm{D}$ value of seawater) during smectite formation.

\section{Mineral Separates}

In order to investigate whether seawater has had any effect on the high-temperature magmatic phases in the basalts, primary unaltered phases from the whole rocks

Table 2. Hydrogen isotope data for selected whole rock samples, Leg 65 .

\begin{tabular}{ccc}
\hline $\begin{array}{c}\text { Sample } \\
\text { No. }\end{array}$ & \multicolumn{1}{c}{$\begin{array}{c}\text { Sample } \\
\text { (interval in cm) }\end{array}$} & $\begin{array}{c}\delta \mathrm{D}(\%) \\
\text { Whole Rock }\end{array}$ \\
\hline 3 & $483-23-1,21-25$ & -105 \\
5 & $483 \mathrm{~B}-22-2,100-107$ & -107 \\
7 & $482 \mathrm{~B}-10-7,49-54$ & -97 \\
8 & $482 \mathrm{D}-9-1,29-35$ & -87 \\
10 & $485 \mathrm{~A}-24-1,77-82$ & -107 \\
12 & $485 \mathrm{~A}-30-1,59-65$ & -94 \\
13 & $485 \mathrm{~A}-30-3,10-16$ & -97 \\
14 & $485 \mathrm{~A}-31-1,41-46$ & -84 \\
15 & $485 \mathrm{~A}-32-1,40-45$ & -94 \\
\hline
\end{tabular}

have been separated and analyzed. Each of these minerals shows a relatively limited spread in $\delta^{18} \mathrm{O}$ values (Fig. 2). Plagioclase varies in $\delta^{18} \mathrm{O}$ from 5.5 to 6.2 , pyroxene from 4.7 to 5.5 , magnetite from 2.3 to 3.9 , and ilmenite from 3.3 to 3.8 . These values are typical of the ranges previously reported for basalts recovered on Legs 45, 46, and 51-53 (Hoernes et al., 1978; Hoernes and Friedrichsen, 1978; Friedrichsen and Hoernes, 1980).

In Figure 3, the $\delta^{18} \mathrm{O}$ values of plagioclase and magnetite are plotted against plagioclase-magnetite fractionation. Within the constraints imposed by analytical uncertainties, the plagioclase values appear to define a trend having a slightly positive slope with decreasing temperature. This type of slope is expected for crystallization of plagioclase in a closed system over the temperature range shown. Had detectable seawater-derived oxygen been present in the magma during crystallization, the $\delta^{18} \mathrm{O}$ values of plagioclase (and other phases) would have been lower for a given temperature, with the result that the slope of the plagioclase trend would be decreased. In the case of the Leg 45 basalts, a slightly negative trend was in fact found for plagioclase, suggesting that a component of seawater-derived oxygen was present at magmatic temperatures (Hoernes et al., 1978). The presence of seawater at magmatic temperatures has also been inferred from oxygen isotope data on certain

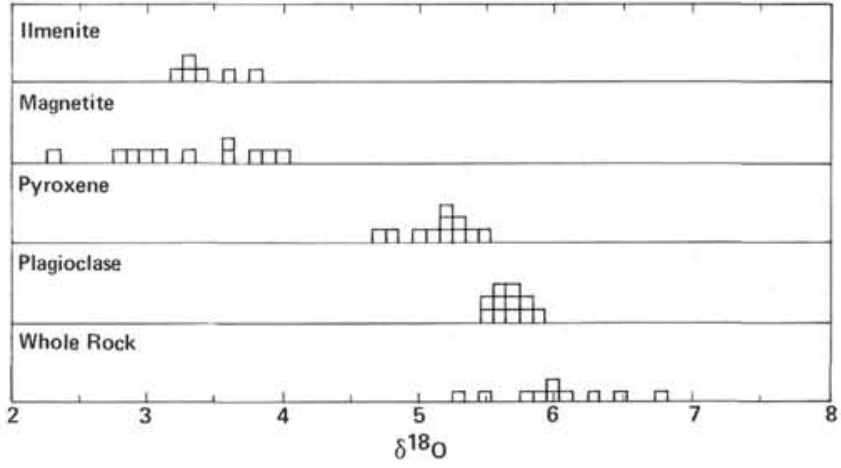

Figure 2. Histograms of oxygen isotope composition of whole rock samples and mineral separates. 


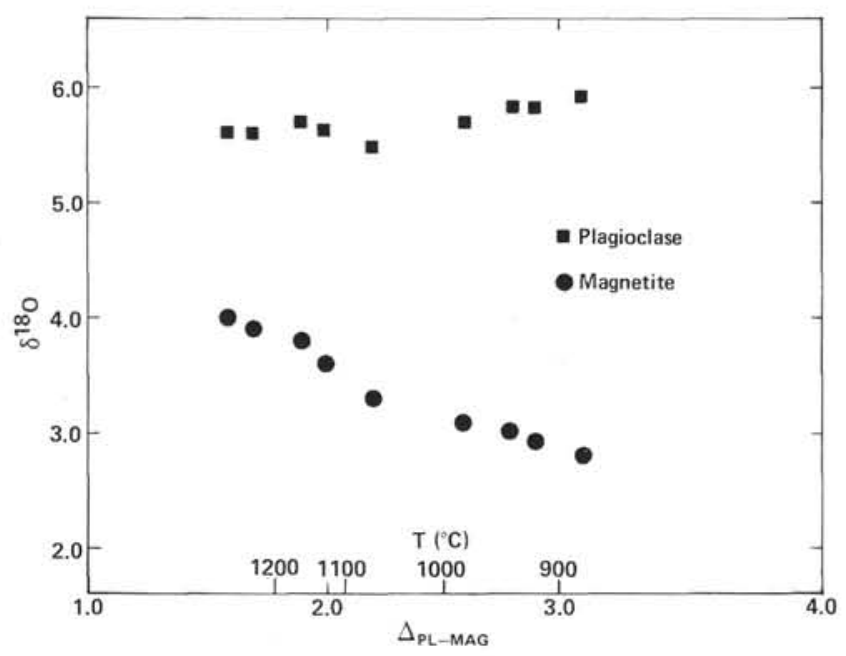

Figure 3. Plot of $\delta^{18} \mathrm{O}$ values of plagioclase and magnetite vs. plagioclase-magnetite fractionation.

Leg 37 samples (Hoernes and Friedrichsen, 1977). In the Troodos and Oman ophiolites, the presence of seawater in the upper levels of gabbro bodies, which represent ancient magma chambers, has been documented on the basis of evidence on isotopes by Heaton and Sheppard (1977), Spooner et al. (1974), and McCulloch et al. (1980).

The lack of seawater in the magma chambers from which the Leg 65 basalts were derived should not be considered an unusual feature, since basalts from Leg 46 , for example, have also crystallized in a closed system with respect to seawater (Hoernes and Friedrichsen, 1978). However, it is perhaps surprising that the magmas apparently did not incorporate any seawater during their emplacement as flows onto, or intrusions into, the wet sediments with which they are interbedded.

The plagioclase-magnetite fractionation values for Samples 12 to 15 (Table 1) are relatively high and imply temperatures on the order of 880 to $980^{\circ} \mathrm{C}$. Interestingly, these samples all come from one thick massive lava unit (Fig. 1), which has a coarse-grained texture characteristic of an intrusive sill. Sample 13, from the central part of the unit, has the coarsest texture and also contains interstitial groundmass quartz. Using the $\delta^{18} \mathrm{O}$ value for this quartz of 7.2, and the quartz-magnetite curves given in Friedmann and O'Neil (1977), a temperature of $860 \pm 40^{\circ} \mathrm{C}$ can be calculated. This presumably represents the final stage of crystallization of a magma which underwent particularly slow cooling.

Two vein carbonate samples yield notably different oxygen and carbon isotope ratios (Table 1). One sample (No. 1), from the highest igneous unit in Hole 483, has a $\delta^{18} \mathrm{O}$ value of 30.0 . Assuming that the carbonate formed in equilibrium with normal seawater, this implies a temperature of formation of $17^{\circ} \mathrm{C}$ (O'Neil et al., 1969). The $\delta^{13} \mathrm{C}$ value of -1.5 for this sample is compatible with precipitation from normal seawater. The other sample (No. 9), from the second highest igneous unit in Hole $485 \mathrm{~A}$, has a $\delta^{18} \mathrm{O}$ value of 25.4 , implying a temperature of $39^{\circ} \mathrm{C}$. However, the $\delta^{13} \mathrm{C}$ value of -5.7 for this sam- ple is lower than the range of carbonates formed from normal seawater, suggesting that the sample precipitated from stagnant pore waters which were depleted in ${ }^{13} \mathrm{C}$ (cf. Muehlenbachs, 1980). If so, the ${ }^{18} \mathrm{O}$ content of the pore waters would also be depleted (cf. Lawrence et al., 1975), and the calculated temperature would therefore be too high. Temperatures of less than a few tens of degrees $C$ for these carbonates are consistent with their location in the uppermost part of the igneous sequences.

\section{CONCLUSIONS}

The oxygen isotope compositions of whole rock basalt samples from Leg 65 are consistent with only limited amounts of low temperature seawater-basalt interaction. In fact, one-third of the samples have $\delta^{18} \mathrm{O}$ values in the range of unaltered midocean ridge basalts. In comparison, the $\delta^{18} \mathrm{O}$ values of basalts from DSDP holes drilled in 3.5 to $110 \mathrm{~m} . \mathrm{y}$. old Atlantic crust are notably higher. The high proportion of massive lava flows and intrusions in the Leg 65 basement may have decreased its overall permeability, leading to reduced seawater-basalt interaction. The relatively high temperature of the Leg 65 basement, and possibly modified seawater $\delta^{18} \mathrm{O}$ values, may also have played some role in producing the low $\delta^{18} \mathrm{O}$ values, but this cannot be assessed from available data.

Mineral separates of the unaltered high-temperature phases display $\delta^{18} \mathrm{O}$ values typical of those previously reported for DSDP basalts. Plagioclase-magnetite fractionation values suggest crystallization under closed-system conditions. This implies that no detectable component of seawater-derived oxygen was present in the basalts at magmatic temperatures, as has been deduced for certain other DSDP basalts. A thick basaltic sill in Hole $485 \mathrm{~A}$ yielded low calculated crystallization temperatures, with groundmass quartz estimated to have formed at 860 $\pm 40^{\circ} \mathrm{C}$; this presumably reflects slow cooling of the sill. Two vein carbonates from the uppermost part of the igneous sequence in Holes 483 , and $485 \mathrm{~A}$ were formed at temperatures of less than a few tens of degrees $\mathrm{C}$.

\section{ACKNOWLEDGMENTS}

We would like to thank J. Maier and C. Schwartz (Tübingen) for analytical assistance, and Dr. T. J. Barrett (Tübingen) for help with the manuscript. This research was supported by the German Science Foundation (D.F.G. Contract No. 357-17, 18).

\section{REFERENCES}

Clayton, R. N., and Mayeda, T. K., 1963. The use of bromine pentafluoride in the extraction of oxygen from oxides and silicates for isotopic analysis. Geochim. Cosmochim. Acta, 27:43-52.

Friedman, I., and O'Neil, J. R., 1977. Compilation of stable isotope fractionation factors of geochemical interest. Data of Geochemistry (Sixth ed.), Geol. Surv. Prof. Paper 440-KK: Washington (U.S. Govt. Printing Office).

Friedrichsen, H., and Hoernes, S., 1980. Oxygen and hydrogen isotope exchange reactions between sea water and oceanic basalts from Legs 51 through 53. In Donnelly, T., Francheteau, J., Bryan, W., Robinson, P., Flower, M., Salisbury, M., et al., Init. Repts. DSDP , 51, 52, 53, Pt. 2: Washington (U.S. Govt. Printing Office), $1177-1182$.

Godfrey, J. D., 1962. The deuterium content of hydrous minerals from the east-central Sierra Nevada and Yosemite National Park. Geochim. Cosmochim. Acta, 26:1215-1245. 
Gray, T., Cumming, G. L., and Lambert, R. St. J., 1977. Oxygen and strontium isotopic compositions and thorium and uranium contents of basalts from DSDP Leg 37 cores. In Aumento, F., Melson, W. G., et al., Init. Repts. DSDP, 37: Washington (U.S. Govt. Printing Office), 607-611.

Heaton, T. H. E., and Sheppard, S. M. F., 1977. Hydrogen and oxygen isotope evidence for sea-water-hydrothermal -alteration and ore deposition, Troodos Complex, Cyprus. Volcanic Processes in Ore Genesis: London (Institution of Mining and Metallurgy and Geological Society), pp. 42-57.

Hoernes, S., and Friedrichsen, H., 1977. Oxygen isotope investigations of rocks of Leg 37. In Aumento, F., Melson, W. G., et al., Init. Repts. DSDP, 37: Washington (U.S. Govt. Printing Office), 603-606.

1978. ${ }^{18} \mathrm{O} /{ }^{16} \mathrm{O}$ and $\mathrm{D} / \mathrm{H}$ investigations on basalts of Leg 46. In Dmitriev, L., Heirtzler, J., et al., Init. Repts. DSDP, 46: Washington (U.S. Govt. Printing Office) 253-255.

Hoernes, S., Friedrichsen, H., and Schock, H. H., 1978. Oxygenand hydrogen-isotope and trace-element investigations on rocks of DSDP Hole 395A, Leg 45. In Melson, W. G., Rabinowitz, P. D., et al., Init. Repts. DSDP, 45: Washington (U.S. Govt. Printing Office), 541-550.

Javoy, M., and Fouillac, A. M., 1980. Stable isotope ratios in Deep Sea Drilling Project Leg 51 basalts. In Donnelly, T., Francheteau, J., Bryan, W., Robinson, P., Flower, M., Salisbury, M., et al., Init. Repts. DSDP, 51, 52, 53, Pt. 2: Washington (U.S. Govt. Printing Office), 1153-1157.

Lawrence, J. R., Gieskes, T. M., and Broecker, W. S., 1975. Oxygen isotope and cation composition of DSDP pore waters and the alteration of Layer II basalts. Earth Planet. Sci. Lett., 27:1-10.
McCulloch, M. T., Gregory, R. T., Wasserburg, G. R., and Taylor, H. P., Jr., 1980. A neodymium, strontium, and oxygen isotopic study of the Cretaceous Samail ophiolite and implications for the petrogenesis and seawater-hydrothermal alteration of oceanic crust. Earth Planet. Sci. Lett., 46:201-211.

Muehlenbachs, K., 1977. Oxygen isotope geochemistry of DSDP Leg 37 rocks. In Aumento, F., Melson, W. G., et al., Init. Repts. DSDP, 37: Washington (U.S. Govt. Printing Office), 617-619.

1980. Alteration and aging of the basaltic crust of the sea floor. In Donnelly, T., Francheteau, J., Bryan, W., Robinson, P., Flower, M., Salisbury, M., et al., Init. Repts. DSDP, 51, 52, 53, Pt. 2: Washington (U.S. Govt. Printing Office), 1159-1167.

Muehlenbachs, K., and Clayton, R. N., 1972. Oxygen isotope studies of fresh and weathered submarine basalts. Can. J. Earth Sci., 9: 172-184.

Muehlenbachs, K., and Hodges, F. N., 1978. Oxygen isotope geochemistry of rocks from DSDP Leg 46. In Dmitriev, L., Heirtzler, J., et al., Init. Repts. DSDP, 46: Washington (U.S. Govt. Printing Office), 257-258.

O’Neil, T. R., Clayton, R. N., and Mayeda, T. K., 1969. Oxygen isotope fractionation in divalent metal carbonates. J. Chem. Phys., $51: 5547-5558$.

Spooner, E. T. C., Beckinsale, R. D., Fyfe, W. S., and Smewing, J. D., $1974 .{ }^{18} \mathrm{O}$ enriched ophiolitic metabasic rocks from $\mathrm{E}$. Liguria (Italy), Pindos (Greece) and Troodos (Cyprus). Cont. Min. Pet., 47:41-62.

Taylor, H. P., Jr., 1968. The oxygen isotope geochemistry of igneous rocks. Contrib. Mineral. Petrol., 19:1-71.

Yeh, H. W., and Savin, S. M., 1977. The mechanism of burial metamorphism of argillaceous sediments: 3. Oxygen isotopic evidence. Geol. Soc. Am. Bull., 88:1321-1330. 